\title{
Coalition and Minority Government in Scotland: Lessons for the UK?
}

\begin{abstract}
The UK general election result in 2010 produced a hung or balanced parliament for the first time in over three decades. Since the UK has limited post-war experience of this outcome it is natural that commentators have begun to look elsewhere for lessons on the practicalities of minority and coalition government. This paper considers the lessons we can learn from the Scottish parliamentary experience since 1999. It outlines two main points of comparison: strength and stability. We might assume that coalition provides more of both than minority government. Indeed, for that reason, it is rare for UK or devolved governments in the UK to operate as minorities through choice. Yet, the Scottish experience shows that the differences between coalition and minority government are not completely straightforward. Much depends on the institutional context and, in many cases, idiosyncratic elements of particular systems. Consequently, we can identify a trade-off in comparative analysis: as our identification of elements specific to one system increases, our ability to draw clear meaningful lessons decreases. ${ }^{1}$
\end{abstract}

Keywords Coalition Government - Minority Government - Devolution - Scotland - Britain

The UK general election of 2010 has produced its first hung parliament since 1974 and commentators have begun to look elsewhere for lessons on the practicalities of minority and coalition government. The search for lessons may be specific and focused on elements most relevant to the UK's 'majoritarian' history. Two features of the Westminster system stand out. First, it usually produces a 'strong' government: it is able to make decisions and initiate policy change quickly, without significant opposition. The 'Westminster model' suggests that power resides within the centre: the electoral system produces exaggerated majorities, allowing the single party in government to dominate Parliament; the government is run by ministers that direct civil servants in departments and by the Prime Minister who controls the appointment of ministers. While this image of UK government is now treated as a caricature, and the literature on governance uses it as a way to describe what doesn't happen, ${ }^{\mathrm{i}}$ the idea of strong centralised government is still powerful and lessons may be sought to ensure a set-up that is as close to the Westminster ideal as possible. Second, it produces relative stability. In parliamentary democracies, the average tenure of a single party majority is 30 months, compared to 17-18 months for coalitions and 13-14 months for minority governments. ${ }^{\text {ii }}$ These features were highlighted as the most important requirements for a UK government by both David Cameron and Gordon Brown in the aftermath of the election result.

This paper considers the lessons on strength and stability that we can learn from the Scottish parliamentary experience since 1999. We might assume that coalition provides more of both than minority government. Indeed, it is rare for UK or devolved governments in the UK to operate as minorities through choice (particularly given its chequered history). Yet, the Scottish experience shows that the differences between coalition and minority government

\footnotetext{
${ }^{1}$ The definitive version is available at wileyonlinelibrary.com.
} 
are not completely straightforward. Strength may refer to the ability of a government to dominate Parliament and its legislative process, but may come at the expense of a single party's ability to dominate ministerial office and the levers of government. Stability may arise from relative immunity to defeats and (in particular) votes of no confidence in Parliament but may be tempered by instability and tension within the machinery of government. Much depends on the institutional context and, in many cases, idiosyncratic elements of particular systems. In other words, we need to identify why particular governing structures produce strength and stability and if those results are likely to be replicated elsewhere. The Scottish Parliament shares many features with Westminster (including a 'Westminster culture' of party tribalism, particularly in the early years when many MPs became MSPs) despite its architects using 'old Westminster' as a source of negative lessons for Scotland's 'new politics'. iii However, key differences remain, such as a more proportional electoral system that virtually guarantees coalition or minority government. Consequently, we can identify a basic dilemma in comparative analysis and our efforts towards 'lesson drawing ${ }^{\text {iv }}$ : as our identification of elements specific to the Scottish system increases, the process of drawing meaningful lessons for Westminster becomes more complicated.

\section{The strength and stability of coalition governments}

One key difference between the Scottish Parliament and Westminster is that the former was designed to be relatively strong, in terms of possessing mechanisms to improve policy scrutiny and the ability of committees to set the policy agenda. It is certainly strong according to Strøm's criteria. ${ }^{v}$ It has permanent and specialized committees with relatively small numbers of members (to foster a collective identity), a combined standing and select committee function (to foster policy expertise within them), a proportional (by party) number of convenors (chairs) selected by a committee, a committee role before the initial and final plenary stages of legislative scrutiny (to foster parliamentary deliberation), the ability of committees to initiate and redraft bills (although perhaps only as a last resort), and the power to invite witnesses, demand government documents and oversee pre-legislative consultation. Yet, the Scottish Parliament did not prove to be strong when compared to the Scottish Executive (renamed the 'Scottish Government' by the SNP in 2007). Rather, from 19992007, the Scottish Labour and Liberal Democrat coalition operated in much the same way as a single party majoritarian government in Westminster, passing an extensive programme of legislation with virtually no effective opposition. ${ }^{\text {vi }}$

From 1999-2007 the coalition provided government strength in terms of its relationship with the Scottish Parliament. Its command of parliamentary seats was sufficient in both sessions. In 1999 it controlled 56\% of the 129 seats (Labour 56 seats and 43.4\%, Liberal Democrat 16 (plus the Presiding Officer), 12.4\%). In 2003 it controlled 52\% (Labour 50, 39\% and Liberal Democrat $17,13 \%)$. The coalition enjoyed a majority in plenary and used it to secure a majority in all select committees. Its impressive party whip and the high degree of voting cohesion within the coalition also ensured stability. There was no equivalent in Scotland to the series of rebellions by Labour MPs in Westminster, partly because Labour MSPs were screened before their selection and because Labour ministers held meetings with Labour MSPs before committee meetings. There were also few instances of Liberal Democrat dissent (and none which threatened the coalition's Partnership Agreement). The coalition gave Labour the sense of control that they feared would be lost if they formed a minority government and were forced to cooperate on a regular basis with other parties. Instead, the coalition produced successive partnership agreements that tied both parties to a detailed programme of legislation and towards supporting the Scottish Executive line (and collective 
cabinet responsibility) throughout. The effect of coalition dominance was dramatic. It controlled the voting process in both committees and plenary. The parties were able to dictate which of their members became convenors of committees and even which MSPs sat on particular committees. As a result, the independent role of committees was undermined as MSPs were subject to committee appointment and then whipped, while committee turnover was too high to allow a meaningful level of MSP subject expertise.

The Scottish Executive presided over a punishing legislative schedule, producing a sense in which committees became part of a 'legislative sausage machine' rather than powerful bodies able to set the agenda through the inquiry process. While there is some evidence of parliamentary influence during the scrutiny of government legislation, the Scottish Executive produced and amended the majority of bills and the government-versus-opposition atmosphere undermined any meaningful sense of power sharing between executive and legislature. The Scottish Parliament and its committees enjoyed neither the resources with which to scrutinise government policy effectively, set the agenda and initiate legislation, nor the independence from parties necessary to assert their new powers. Overall, the experience was heartening for a Scottish Labour party that prized above all else a 'settled programme' and feared the prospect of political embarrassment from political ambushes led by the SNP that they feared and loathed so much.

Identifying strength and stability within the coalition is a separate matter. The price that Labour paid for a settled legislative programme was systematic cooperation, and the need to compromise, with the Liberal Democrats. The process of compromise was made easier by the ideological closeness between the parties, but a number of issues demonstrate the unpredictability of outcomes. On the one hand, the overall experience shows that the Liberal Democrats, as the smaller party, was willing to live with major policy compromises to secure a small number of key aims. For example, although it favoured the abolition of higher education tuition fees, it accepted the abolition of up-front fees combined with a reduction in the graduate contribution or 'endowment' (£2000 for 4 years at University). It also accepted from 2003 a shift in direction of justice policy towards populism and an agenda on tackling anti-social behaviour, despite the fact that it had secured from 1999-2003 (during Deputy First Minister Jim Wallace's term as Justice minister) a different approach and key differences with the UK on issues such as freedom of information. ${ }^{\text {vii }}$ In part, it did so to secure its aim of PR in local government elections (note that Labour agreed to legislate to make this possible from 2007; in the UK the deal is merely to allow a referendum on AV, with Conservative MPs free to argue against it).

On the other hand, the example of free personal care for older people demonstrates the potential instability of coalition government. In this case, Scottish Labour decided initially to follow the UK Government by rejecting the Sutherland report's recommendation of free care (not least because UK Labour ministers put pressure on them to do so). Yet, the Liberal Democrats favoured the policy and threatened to break ranks and join forces with the SNP and Conservatives to pursue the matter through legislation. The outcome was a Labour reversal, with Henry McLeish (First Minister) famously appearing on Newsnight Scotland to claim the decision for himself. The example demonstrates that coalition governments can survive such periods of instability, although it is difficult to know how far these matters can go before the coalition breaks down. In this case, Scottish Labour was sympathetic to Sutherland and backed down to ensure governing stability. In other cases, such as the future of nuclear power, the parties agreed to defer a decision beyond their period of government because they could not agree. 
The wider process of cooperation involved systematic policy coordination, in which both parties were to be consulted routinely on major policy decisions and decisions made by ministers within individual departments, requiring extensive information sharing and permission-seeking between civil servants in all departments. At face value, this requirement may seem rather appealing. A major theme in UK policymaking is that, despite a commitment to sharing information, the government consists of a series of policy silos organised around departments. Each department has its own aims, constituencies and policy networks and joined up government has often remained elusive, despite attempts by the New Labour Government to pursue its 'modernization' agenda through cross-cutting targets coordinated from No.10 and then by the Treasury through public service agreements. Yet, the Scottish experience does not give a clear sense that a UK coalition government will improve policy coordination. In part, this is because Scottish negotiations took place in a different context (not only because the Executive is smaller, with fewer responsibilities). The legacy of the Scottish Office (the pre-devolution UK government department) arrangement, in which there were few ministers, is that ministerial responsibilities spanned multiple government departments. The greater potential for joined up government was already there. However, there was still evidence that policy silos existed (for example, higher education or agricultural networks were not altered significantly when combined with other issues in new departments), while the cross-departmental arrangements often produced evidence of confusion over which agencies or quangos were responsible to particular ministers. The classic example arose when the Scottish Qualifications Authority failed to produce reliable exam results and no-one knew exactly which minister to hold accountable. In other words, Scotland may be better at providing a cautionary tale: a coalition government's increase in reporting and accountability arrangements may exacerbate the sense of diminished individual ministerial responsibility that we now find in the era of multi-level governance.

The Scottish experience can also provide lessons on the limits to collective cabinet responsibility. ${ }^{\text {viii }}$ On the whole, the partnership agreement, combined with a commitment to cooperate, ensured that few major issues of public disagreement arose (indeed, Labour party dissent and in-fighting was more worrying than disagreements between the parties). In theory, the convention is that when a decision has been reached by Cabinet, all members are obliged to defend it publicly. In practice there are always grey areas and the conventional limits take time to define. For example, the first major test in Scotland involved ministers addressing constituency matters on an issue (specific hospital closures) that had an indirect link to government policy (the centralisation of certain NHS services). A minister expressed opposition to the hospital reorganisation plans of a health board (approved by the Scottish Executive) but voted with the Scottish Executive in Parliament and remained in government; a Ministerial Parliamentary Aide voted against the Executive and resigned. Thus, the parliamentary vote appears to be the line in the sand. This conclusion was reinforced during similar debates such as the firefighter dispute in 2003. It is also supported by the outcome of debates on reserved issues such as Trident, the Iraq War and 'dawn raids' on failed asylum seekers. While ministers were relatively free to criticise UK government policy (since they were not bound to CCR as members of the UK cabinet), they were still expected to resign if they voted against the Executive in a Scottish Parliamentary motion. For example, Malcolm Chisholm remained a Labour minister after criticising directly, on TV, the UK Government policy on asylum, but resigned when voting with the SNP on a motion to oppose Trident bases in Scotland. In most cases, the convention was breached by Labour and not, as expected, Liberal Democrat MSPs (who were relatively free to criticise key UK policies while remaining in the coalition). In some cases, we can perhaps relate it to the feeling among members of the largest party that their message is being diluted through coalition. 
The sense of exclusion caused by coalition may produce more tensions within a party than across them.

\section{The strength and stability of minority governments}

The Scottish experience of minority government from 2007 provides fewer direct lessons for the UK, but it highlights to some extent a trade-off between strength and stability in Parliament versus strength and stability in government. The SNP minority government commands only 47 seats (36\%) and, whilst vulnerable to motions of no confidence (a simple majority is required to oblige the executive to resign), has not faced any. It has lasted well beyond the international average and should complete a full 4-year term. Its minority status has made it relatively 'weak' in terms of its relationship with the other parties in Parliament (in both plenary and committees) but there have been surprisingly few instances of real problems that threaten its governing status (particularly when there is still a strong government-versus-opposition tone in plenary and the opposition parties often suggest that SNP ministers are lying in Parliament).

The SNP has had to drop some legislation for which it does not have parliamentary support. Most significantly, it dropped its commitment to introduce a bill to produce a referendum on independence when the three other parties refused to support it. It also dropped its plans to pursue a local income tax to replace the council tax when it could not secure the support of the Liberal Democrats (there were also problems related to the loss of council tax benefits, amounting to $£ 4-500 \mathrm{~m}$ ). However, it has had some high profile successes, including a bill to abolish the graduate endowment (and, less importantly, to abolish bridge tolls). Overall, it has produced a respectable number of bills (it will likely produce 40 in 4 years, compared to 50 and 53 in previous sessions) in the context of its commitment to reduce legislation (there was a widely held perception in the Scottish Parliament that there was too much from 19992007) and govern competently rather than seek innovation constantly. Its ability to pass so many bills reflects the fact that a large proportion of government business in Parliament is rather innocuous. There is little incentive for the opposition parties to oppose the principles of, for example, a bill reforming flooding policy. The SNP also inherited many bills from its predecessor government (on issues such as the need to prepare for the commonwealth games, reform the judiciary and courts, reform public health law, and revise the law on sexual offences).

The SNP loses many parliamentary motions, but most are non-binding motions that merely set the agenda for the Scottish Government. Indeed, following a motion in 2007 calling on the Scottish Government to fund the Edinburgh Airport Rail Link and tram project, Alex Salmond drew on comments made by former First Minister Donald Dewar to suggest that he was not bound by parliamentary motions (the trams were funded but EARL was not). SNP whips and business managers have since sought to avoid similar confrontations by negotiating the wording of motions with their counterparts in other parties and acting on many motions. It is more vulnerable to opposition party amendments to its legislation, but 'wrecking' amendments are subject to stricter rules than in Westminster amendments' (amendments that threaten the spirit and tone of the bill are rejected by the Presiding Officer or committee convenors) and, in some cases, there is a limit to the overall cost of a bill's provisions.

Overall, the approach taken by the other parties is that the SNP may often be doing the wrong thing but it has the right to try. A common or ideal image of minority politics suggests that parties take a positive attitude towards cooperation; they find reasons to pursue common 
policy ground. While parties will disagree on many issues overall, a minority government should be able to form a series of deals with different parties at different times. The Scottish Parliament may not live up to this consensus democracy ideal, but parties with a majoritarian history and culture do the next best thing: they work within the confines set by minority government, taking on the traditional Westminster role of parliamentary scrutiny and opposition without initiating much legislation or representing an alternative source of policy initiation, even in high profile cases with significant policy distance between the Scottish Government and Parliament. For example, while the three opposition parties were heavily critical of the Scottish Government's decision to release the Lockerbie bomber on compassionate grounds, they did not seek to overturn the decision.

Some of the stability of minority government can also be traced to the informal coalition between the SNP and the Scottish Conservative party. The Conservatives have voted with the SNP on a staggering 72\% of parliamentary motions since 2007 (compared to 94\% agreement between Scottish Labour and Liberal Democrat from 2003-7). ${ }^{\text {ix }}$ The effect of Conservative support has varied because it is not sufficient to command a parliamentary majority (the Conservatives have 16 MSPs plus the Presiding Officer), but it represents an important source of support in exchange for policy concessions. The best indicator of its effect can be found in the annual budget bill process. In the first budget, the Conservatives secured a greater commitment to funding new police officers and revisit drugs policy. In the second, they secured a reduction in business rates. In the third, they secured an independent review panel on future budgets and an agreement to publish online items of government expenditure of $£ 25,000$ or above. ${ }^{\mathrm{x}}$ In two of three years, Conservative support proved to be sufficient because Labour (46 seats) abstained in 2008 and the Liberal Democrats (16) abstained in 2010. Only in 2009 did both vote against the bill on the assumption that this would not lead to its failure (most expected the two Green MSPs (and Margo MacDonald) to vote with the SNP in exchange for increased funding for home insulation). This failure was followed very quickly by a new bill, passed in a few weeks, that was almost identical to the old.

The SNP's relative lack of strength and stability within the Scottish Parliament contrasts to some extent with its position within government. Its period in office has been relatively straightforward. Its cabinet of six (compared to 12 in the coalition and over 20 in the UK) provides the potential for more meaningful cabinet decision making. There have been no major tensions in policy aims comparable to those faced by the Scottish and UK coalitions. Its single-party status reduces the need to coordinate policymaking to the nth degree. This lack of internal problems allows it to exploit the asymmetrical relationship between the Scottish Government and Parliament. While the SNP has had to reduce its major legislative commitments, it has found that it can pursue many agendas without recourse to Parliament. Numerous policy aims (on intergovernmental relations, the civil service, capital finance projects, public service targets, curriculum reform, prescription charges) can be pursued without using legislation, while others can be pursued using the legislation that exists (i.e. with secondary legislation and regulations much less subject to parliamentary scrutiny).

Further, most of the conditions associated with majority government still apply. Small committee size and MSP turnover still undermine the abilities of committees to scrutinize government policy and the huge gulf in resources remains. While the opposition parties, if united (and bearing in mind that the Conservatives have been supportive of government on over $70 \%$ of motions), may be able to oppose certain measures, they do not have the resources to scrutinise policy in great detail or provide meaningful alternatives. This situation is not altogether surprising because, despite the range of Scottish Parliament 
'powers', it was not designed to be a policy initiating body. Rather, the institution represents an attempt to improve on the scrutiny powers of Westminster without marking a profound change in the executive-legislative relationship. Committees have the power to hold ministers and civil servants to account, to make sure they consult properly and to initiate legislation as a last resort if MSPs believe that government policy is inadequate. Yet, they are also instructed by the Consultative Steering Group (the group set up to produce the Scottish Parliament's standing orders) to let the government govern, encouraged to play a minimal pre-legislative role and, in the case of the budget, not equipped to develop alternative legislation. The Scottish Parliament even lacks Westminster's equivalent of a 'scrutiny reserve' for EU issues.

The Scottish experience has given the parties a new impression of minority government that may influence party strategies in 2011. For the two large parties, Labour and SNP, minority government represents an attractive option. Minority government may allow a party to make up for its weakness in plenary with its strength in government staffing resources and a reduced need to make compromises within government. Further, unlike in a majority coalition, defeats on parliamentary motions can be brushed off with relative ease. However, it is difficult to identify enough policy influence for opposition parties to give them an incentive to eschew public office when it is available and support minority government. This is not really an issue for the Conservatives who are not likely to be offered the chance to form a government and will therefore benefit more from minority government (note that there is no equivalent in the UK to the Scottish Conservative position). However, the lack of policy influence enjoyed by the Liberal Democrats since 2007, compared to its coalition experience, seems to diminish the probability that it will accept minority government in the future. If the Liberal Democrats in the UK (the only powerful smaller party) take notice of the Scottish experience, we may expect coalition government to be much more likely than minority.

There are several additional reasons to expect more coalitions in the UK than Scotland. First, UK policy responsibilities are more significant and the stakes are higher. In Scotland there are fewer fundamental issues to polarise party opinion and produce damaging defeats. The Scottish Parliament is not responsible for the big economic decisions on fiscal and monetary policy or taxation and redistribution. Further, there is no Scottish equivalent to the agenda on welfare reform that is likely to divide the parties, or many other potential hot button topics that could produce significant conflict, such as defence policy and the future of Trident. Second, the effect of a perception of instability is more marked at the UK level. For example, there is no equivalent in Scotland to the idea that governing uncertainty 'spooks the markets'. Third, the UK has a second chamber and the lack of a majority in Westminster may affect its relationship with the House of Lords (the extreme example would be a reduced ability to threaten to use the Parliament Act). In each case, the larger party may be as likely to seek coalition as the smaller. Fourth, the UK cannot draw on a developing culture of cooperation. In Scotland, PR elections produce an expectation that parties will always have to cooperate to some degree. In the UK, we have no such clear expectations, even if we expect modern voting patterns to produce more hung parliaments than in the past.

Yet, such differences may be exaggerated. For example, under a plurality system the opposition parties have the chance to force an extraordinary election to further their positions following a short period of unsuccessful of government. However, no party wants to be blamed for an extra election, particularly during a time of economic crisis. Further, minority government is by no means limited to situations like Scotland's where the stakes are relatively low. Rather, according to Strom, it can be found in one-third of all parliamentary democracies. 


\section{Conclusion: Lessons for the UK}

There are three main lessons to arise from this discussion. First, coalition government secures government strength in Parliament but may make the task of government more complicated. The Scottish Executive coalition operated effectively as a single party majoritarian government in the Westminster mould. It dominated plenary and select committees, allowing it to pursue a wide variety of policy aims through legislation. However, the need for compromise and systematic cooperation provides the potential for weaker governing arrangements. The process of coordination among parties can become rather convoluted, while the increase in reporting or accountability arrangements (to both ministers and parties) may exacerbate the diminished sense of accountability in one individual that we now encounter in an era of 'governance'. A majoritarian government is able to make decisions and initiate policy change quickly, without significant opposition. A coalition or minority government may have to settle for one and not the other.

Second, coalition arrangements may produce stability in Parliament but exacerbate tensions within parties. In Scotland, the coalition majority, combined with a strong party whip, ensured a 'settled programme'; the Executive passed virtually all of its legislation without any significant opposition or radical amendment and it suffered only a handful of defeats on non-binding motions over eight years. At the same time, the need to produce a formal compromise produces occasional dissatisfaction, particularly among members of the larger party faced with a new obstacle to policy influence. Given the slimness of the Conservative/ Liberal Democrat majority in Westminster, it will not take much of a rebellion to threaten the coalition's position.

Third, the Scottish experience suggests that minority government presents a realistic alternative to coalition, particularly when a party in opposition is willing to provide consistent parliamentary support in exchange for policy concessions. However, the UK context may be more complicated. The UK has no equivalent to the Scottish Conservatives: content to make deals in opposition because it has a minimal chance of being part of government (and because it may help the party's profile in Scotland). Instead, it has a single kingmaker in the shape of the Liberal Democrats, which might analyse the Scottish experience and find no incentive to remain in opposition. The stakes are also higher in the UK, producing in parties a desire to seek stability in coalitions (particularly since they have no history of cooperation to draw upon).

However, whether or not any lessons will be learned is another matter. The general picture of lesson drawing in the UK is that the UK government prefers to learn policy lessons either from the US or from countries such as France or Germany that are of a similar size and face comparable problems. It tends not to learn from the devolved territories. ${ }^{x i}$ In contrast, the Liberal Democrats are more likely to share lessons across the party. For example, Jim Wallace (former deputy First Minister) advises its UK leadership from the Lords (and sits on key Lords committees), while David Laws MP was part of the negotiations in Scotland. Both may draw on the suggestion that the civil service tends to be closer to the larger party during the initial negotiations. The 'triple lock' system was also evident in Scotland (albeit in a different form). ${ }^{\text {ii }}$

There are also shared concerns that point to the wider potential for shared ideas. In particular, no party in the UK or devolved governments seem prepared for government formation. Perhaps the association of a hung parliament with instability will change if the rules of government formation change or, more accurately, if the UK introduces some rules. 
The UK may also provide lessons for a future coalition government in Scotland. In particular, it is the first coalition government to face the need for funding cuts. In Scotland from 1999-2007 the coalition government enjoyed an unusual rise in its budget. While it had to make compromises, the hard decisions were just not as hard. The UK enjoys the first crisis coalition government.

\footnotetext{
${ }^{\text {i }}$ Bache, I. and Flinders, M. 'Multi-level Governance and the Study of the British State', Public Policy and Administration, 2004, 19, 1, 31-51

${ }^{\text {ii }}$ Muller, W. and Strøm, K. eds. Coalition Governments in Western Europe, Oxford: Oxford University Press, 2003, p. 1

${ }^{\text {iii }}$ McGarvey, N. and Cairney, P. Scottish Politics, Basingstoke: Palgrave, 2008

${ }^{\text {iv }}$ Rose, R. Learning from Comparative Public Policy: A Guide to Lesson-Drawing, London: Routledge, 2006

${ }^{\vee}$ Strøm, K. Minority Government and Majority Rule, Cambridge: Cambridge University Press, 1990

${ }^{\text {vi }}$ Cairney, P. 'Coalition and Minority Government in Scotland', paper to Political Studies Association annual conference, Edinburgh, April 2010

${ }^{v i i}$ Keating, M. The Government of Scotland $2^{\text {nd }}$ ed., Edinburgh: Edinburgh University Press, 2010.

${ }^{v i i i}$ Cairney, P. The Scottish Political System Since Devolution, Exeter: Imprint Academic, 2011.

${ }^{\text {ix }}$ MacGregor, S. 'Voting Behaviour in the Scottish Parliament', Paper for the Elections, Public Opinion and Parties Annual Conference, Essex, September 2010

${ }^{\mathrm{x}}$ The fourth may prove more troublesome - see http://paulcairney.blogspot.com/2011/01/scotland-monitorjanuary-2011.html

${ }^{\mathrm{xi}}$ Cairney, P., Keating, M. and Hepburn, E. 'Policy Convergence, Transfer and Learning in the UK under Devolution', ESRC Seminar on Policy Learning and Policy Transfer in Multilevel Systems, Edinburgh, January 2010

xii Information from Mark Oaten, Tim Bale and Emma Sanderson-Nash, University of Sussex seminar, October 2010. Thanks also to Matt Flinders for comments on an earlier draft.
} 